\title{
Improving Polri Performance Management Online Practices In Polrestabes Surabaya East Java
}

\author{
Muhammad Ade Rizky Fitriawan, Rachma Fitriati \\ Faculty of Administrative Science Universitas Indonesia, Depok 16424 and Indonesian National Police \\ Headquarters ${ }^{1}$; Faculty of Administrative Science Universitas Indonesia Faculty of Administrative \\ Science Universitas Indonesia, Depok 16424, Indonesia ${ }^{2}$, \\ Coresponsing author: rachma.fitriati@ui.ac.id
}

\begin{abstract}
The Performance Evaluation of Indonesian National Police-INP initially used a system using an assessment list. But this system is no longer in line with the current development needs of the National Police Human Relation. For this reason, a revision to Perkap Number 16 of 2011 concerning Performance Assessment for Civil Servants of INP with a Performance Management System became the Regulation of the National Police Chief Number 2 of 2018 concerning Performance Evaluation of Members of the Indonesian National Police. This study uses a qualitative approach. The results of the study indicate that the implementation of performance appraisal has so far only pursued formalities and aborted obligations. The lack of knowledge and awareness of personnel regarding Perkap Number 16 of 2011, which causes the performance evaluation to be not optimal. The results of this study also show that the provision of innovative rewards and punishment such as free umrah (for Muslim police personnel) and punishment that provides learning - namely verbal reprimand from superiors and compulsory reporting, is one of the keys to improving innovation in evaluating the performance of the Indonesian National Police personnel to increase motivation to improve performance.
\end{abstract}

Keywords: Performance Management System, Performance Appraisal, Employee Performance, Performance Measurement

\section{Introduction}

Human Resources (HR) in organizations is a crucial aspect that determines the effectiveness of an organization. Professional and reliable human resources from work dedication and performance [1]. Careful measurement of performance this time with the performance, achievements and work capabilities of people in the organization [2]. Similar to the police of the Republic of Indonesia, HR is the main one in determining a conducive society. This is stated in the Three Life Guidelines - Tri Batra, which is always protected, nurturing, and serving the community with sincerity to realize security and order. The Performance Approval process for the implementation of the Indonesian National Police (INP) was conducted a long time ago.

Initially, the performance evaluation of members of the Indonesian National Police (INP) (Kepolisian Negara Republik Indonesia-Polri) was carried out using a list of values. List of values as a measuring tool in the conceptual is expected to be provided in the previous section and predicts the results of future work. Then the list of values is also performance-oriented 
(oriented to excellence) based on individual competence, upholding the value of the profession (integrity), a system that can be traced to a logical and auditable path from the individual level to the Indonesian National Police Institute (accountability), openness, trust, benefits conferences and differences in accordance with requirements, determine the basis of knowledge and recognition in accordance with qualifications, solve problems and take systematic decisions, thereby strengthening the new paradigm that contains the values of independence, openness and professionalism. However, in the field discussion, the list of values process issued using the Indonesian National Police at that time had many weaknesses, it was necessary to refute objections to its objectivity. Performance appraisal with list of values has no effect on the career development of members. The list of values's assessment is only used for educational and training activities, not really to measure and improve personnel performance [3].

This can be achieved if there is a system of recruiting, developing, motivating and evaluating $\mathrm{HR}$ as a whole to the needs of the organization to achieve its goals (http: // vmicrolearning.ssdm.polri.go.id/course / training-coaching-development-human resource / police /). To increase Polri's resources, resource development is carried out through activities to increase the number of personnel through recruitment and selection, education and training, use, maintenance and termination of service.

The development of the police force through recruitment is also found in the process of human resource management, which places assignments according to the capabilities and expertise of the members, as well as career guidance in regional units (satwil), work units (satker), and functional units. Career development itself, by promoting positions or promotions based on the principle of the right person on the right place and the merit system. This is in line with Gary T Marx's opinion in Police and Democracy which explains that there are three important elements about democratic policing: first, working in accordance with the legal norms and rules set in a country; second, full respect and respect for human rights, and third, implementing a public accountability system [4], [5].

On the other hand, the figure of a member of the Indonesian National Police must be able to play a role in accordance with the third tri brata, which is always to protect, nurture, and serve the community with sincerity to realize security and order. Polri members must have the ability and expertise to indicate a professional attitude, be it disciplined, have good morals, show loyalty and obedience to the state, be responsible for their duties and functions as state servants and public servants.

The Human Resources Management improvement program is a strategic step for the Indonesian National Police in responding to the demands of the community towards improving the Polri performance culture. Some empirical studies prove that the implementation of policies is also strongly influenced by the management of human resources carried out by organizations, which affect a number of systems and performance patterns of members / employees [6]; [7] , organizational culture [8], as well as the desired policy output[9]; [10].

Several studies have shown that the existence of performance appraisals can improve the consistency of police performance as an effort to realize organizational goals and can increase job satisfaction of police officers [11]-[14]. Furthermore, an empirical study conducted by Luen \& Hawamdeh (2001), found that measuring staff performance as a manifestation of human resource management, which must be aligned with other actions such as education, 
training and staff motivation to effectively improve the ability of police officers and therefore allows them to carry out their duties optimally.

Performance Appraisal that is currently used in Personnel The National Police Regulations in the National Police Regulation [16] No. 2 of 2018 article 1 paragraph 24 discusses the Performance Assessment Information System (Sistem Informasi Penilaian Kinerja-SIPK) is a computer-based system that can receive, send, store, process, and present data and information about Approval of the performance of Polri members online that is accurate, quality, and timely as support for the management of vocational school [17]. In the Regulation of the National Police Chief Number 2 of 2011 Article 5, the renewal of the decisions of the National Police officers is carried out through Vocational Schools to include performance planning, performance evaluation, performance evaluation, and performance [18]. In the regulation, article 6 of the decision consists of specific factors and genetic factors, with the weight of each specific factor is $60 \%$ and generic factors are $40 \%$ (article 20). The Regulation of the National Police Chief Number 2 of 2018 came into force on January 1, 2019, including in Surabaya Resort Police (Polisi Resor Kota Besar-Polrestabes) [19].

Surabaya Resort Police is the frontline that requires conduciveness in one of the major cities in Indonesia. All members of the Indonesian National Police have a high workload so they are demanded to have good needs. Surabaya Resort Police of course also enacts Regulation of the National Police Chief Number 2 of 2018 to assess the quality of its members. Of course, this is a new thing that must be owned by members of the Indonesian National Police in particular members of the National Police in Surabaya Police. With this in mind, this study aims to describe the application of the online-based National Police assessment system at Surabaya Resort Police [20].

\section{Method}

This study uses qualitative methods [21]-[23]. Qualitative methods are carried out by involving content analysis [24] and data collection techniques in the form of observations, literature studies, in-depth interviews and FGDs [25]. In addition, the data was also obtained through direct observation on Surabaya Resort Police to see the implementation of a performance management system (Sistem Manajemen Kinerja-SMK-Online), and supported by literature studies and related licenses.

\section{Result}

Performance management is the need of every organization. Performance management is oriented to work processing and work results. It can also be interpreted by financial management to control and validate organizational goals. The performance appraisal system in the National Police organization is one of the systems developed by the National Police organization with the aim to boost the performance of the National Police personnel. The performance appraisal system of the National Police personnel is implemented based on the National Police Chief Regulation Number 16 of 2011 concerning Performance Appraisal for civil servants in the Republic of Indonesia National Police with a performance management 
system (Sistem Manajemen Kinerja-SMK-online). The Republic of Indonesia National Police personnel performance approval system approved in Perkap Number 16 of 2011 has links with the rights of members of the National Police personnel. These rights are issued: performance allowance (based on Presidential Regulation number 73 of 2010 and National Police Regulation Number 6 of 2011), promotion process (on the basis of the Police Chief Skep Number: Skep / 232 / IV / 2005), process of increasing income, vocational and development, the award process (based on Perkap Number 3 of 2011) and other rights.

In line with the opinion of Mathis and Jackson (2006); Aktar and Pangil (2017), explain the assessment of an organization that can provide information about the organization such as what is related to employees related to information regarding the determination, training and development, promotion, and others. Furthermore, it also reviews effective reforms that discuss two things, namely: (a) the existence of a separate standard and (b) information communication [3], [26]. Mathis and Jackson's statement was approved by Dessler (2013) which explains that "Effective assessment also requires that supervisors set performance standards. And that requires that employees receive the training, feedback, and incentives needed to eliminate performance deficiencies. "[27].

Initially, evaluations of the performance of Polri members were carried out using a list of values. In the program, this was thought to be incompatible with existing developments, so in 2010 the Indonesian National Police through HR Deputy Regulation No. 1 of 2010 Then passed through Perkap number 16 of 2011 concerning Performance Assessment for Civil Servants of the Republic of Indonesia National Police with a Performance Management System. On the journey of implementation of Perkap number 16 of 2011 more discussed, as discussed by HR Polri with material Polri Vocational School. Some of these problems are those that are often manipulated, effectively subjective and not yet based on information technology. Based on this, the National Police revised and added a number of discussions and installed information technology as an implementation strategy through National Police Regulation No. 2 of 2018 concerning Performance Evaluation of Members of the Indonesian National Police. Overview Process of Polri Vocational School-based online.

Surabaya Resort Police has been implementing SKM online since January 2019. SKM Online is expected to help win Polri members, making it adaptable to make compensation adjustments. In line with the research results of Aris et al (2017) explaining the assistance program that can be done for existing programs in compensation and benefits, leaders can make decisions in the arrangement of financial assistance improvement according to the agreement on performance [7]. The results of the Vocational High School can also be a basic material for providing training within the framework of increasing membership so that each member has competencies in accordance with the standard competencies that are in accordance with the needs of the Surabaya Resort Police organization. But there are also weaknesses in the application of Vocational Schools, namely the emergence of doubts about officials who are questioned about the objectivity of the assessment of the performance carried out, will lead to a decline in work motivation and related tasks only as routine tasks and improvement of motivation for achievement [27]. 
In line with the results of research conducted by Ambarwati (2014) explains that leaders are often confused in the assessment of members for this reason reported will discuss family members who will discuss the seriousness in carrying out their responsibilities. And agreeing to get good grades will have an impact on negligence in carrying out work by assuming that employees in job control have met the standards [28].

If examined further on Perkap number 16 of 2011 concerning performance appraisal for civil servants in the National Police with the Performance Management System, it is explained that in the regulation there are 4 (four) principles in the assessment. The four principles are (1) transparent, (2) clean, (3) accountable, and (4) objective. Transparent, which means that the performance appraisal is carried out openly, by agreeing on five performance factors that will be assessed by the Appraisal Officer and the Appraised Officer and the results of the appraisal will be delivered directly. Whereas clean, which implies that in carrying out the performance appraisal there is no blemish for the Appraisal Officer and the Assessed Member to conduct KKN because in the implementation of the appraisal also involves two fellow Assessed Member who is chosen at random. Then accountable, is that performance appraisals can be accounted for vertically or horizontally. And then objectively, it means that performance appraisals are carried out in accordance with agreed performance facts and results in accordance with agreed targets.

The implementation of performance appraisal at the Surabaya Resort Police and its staff, analyzed with the four principles of performance appraisal above, is for the transparent principle to be difficult to achieve. This is because in the preparation of specific performance factor (FS) indicators that should be agreed between the Appraisal Officer (PP) and the Assessed Employee (PYD), but in its implementation is not based on an agreement based on the basis of performance determination, but compiled by the staff of bagsumda, paurmin, kaurmin and kasium. Then for the principle of accountability, it is difficult to carry out accountability assessments. Because in the preparation of assessment indicators, especially specific factors are not based on the PYD job description, the valuation is only a formality and origin. This will result in accountability both horizontally and vertically will be ignored.

Furthermore, based on objective principles, that as long as the assessment process is still formal and careless, objective principles will be difficult to achieve. Even what happens is the element of subjectivity that will emerge. That is because by not doing procedurally correctly in the implementation of the assessment, the majority of the assessment process carried out by the HR function browser becomes subjective for the leadership and personnel carrying the HR function. Coupled with the target written in the specific performance agreement is not based on agreement (carelessly) then the performance carried out by PYD will be careless too.

\section{Discusion}

Performance appraisal of personnel is principally carried out on all members of the Indonesian National Police, including Surabaya Police. This performance appraisal is also carried out on 
personnel who are in the average output, or on personnel who are performing or who are under repair. In accordance with the implementation, Regarding people, also using the National Police Performance Management System in accordance with Perkap Number 16 of 2011 [18].

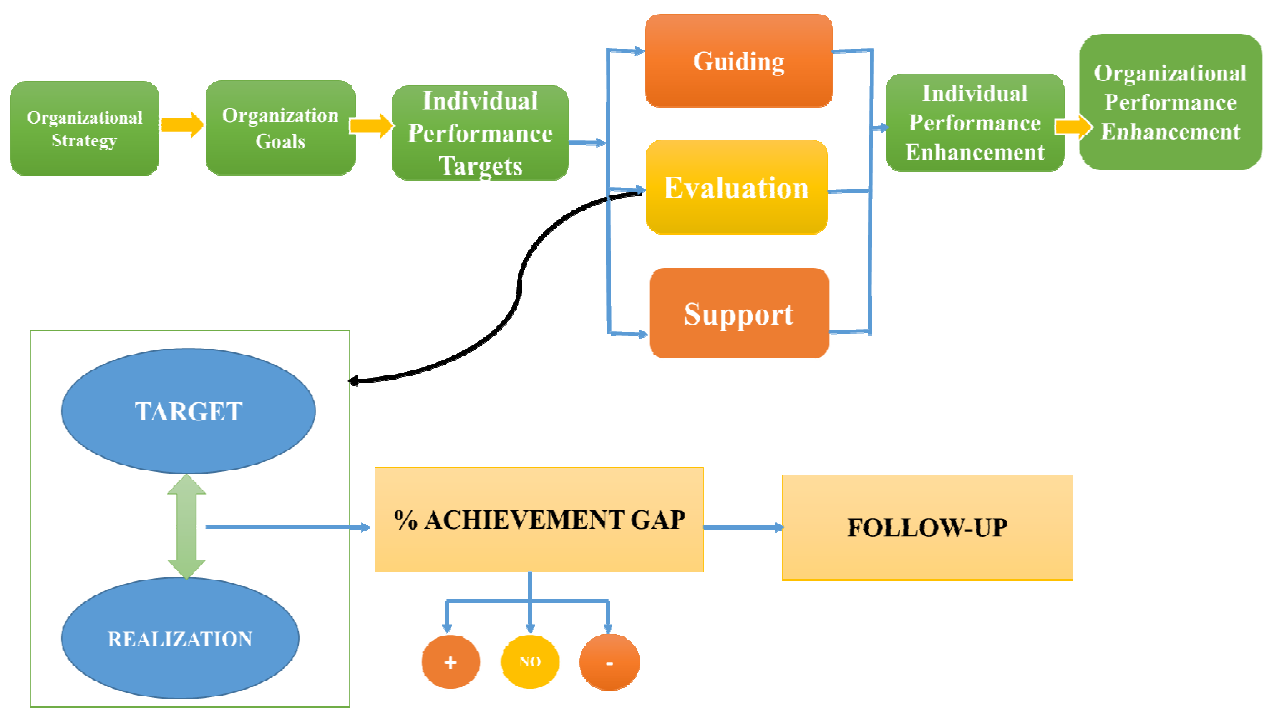

Source: SSDM Polri, 2019

Figure 1. Concept of Performance Evaluation

Then an assessment is conducted both in Semester 1 and Semester 2 (figures 2 and 3)

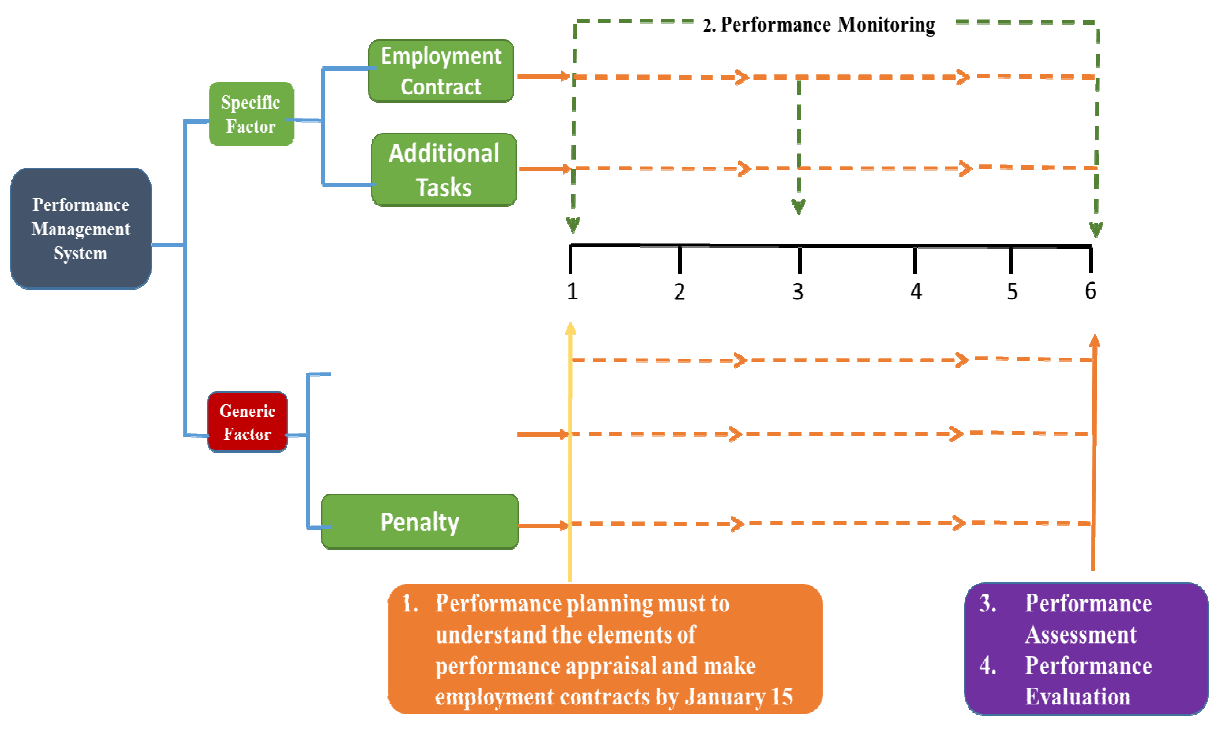

Figure 2. Flow Chart of Perkab Online Performance Management System 


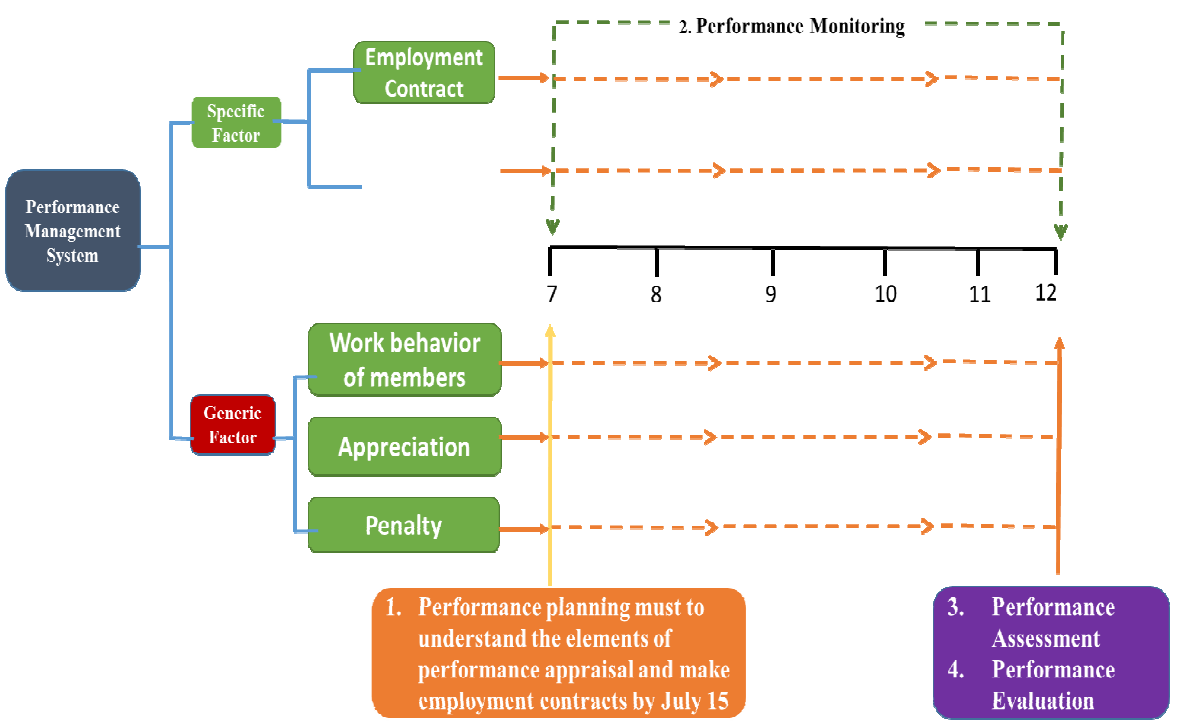

Source: SSDM Polri, 2019

Figure 3. Flow Chart of Perkab Online Performance Management System Term I

Then the Flowchart of Online SMK Vocational Planning Semester 1 and The Flow of Graft Online Vocational School Semester 2 are combined into one definition

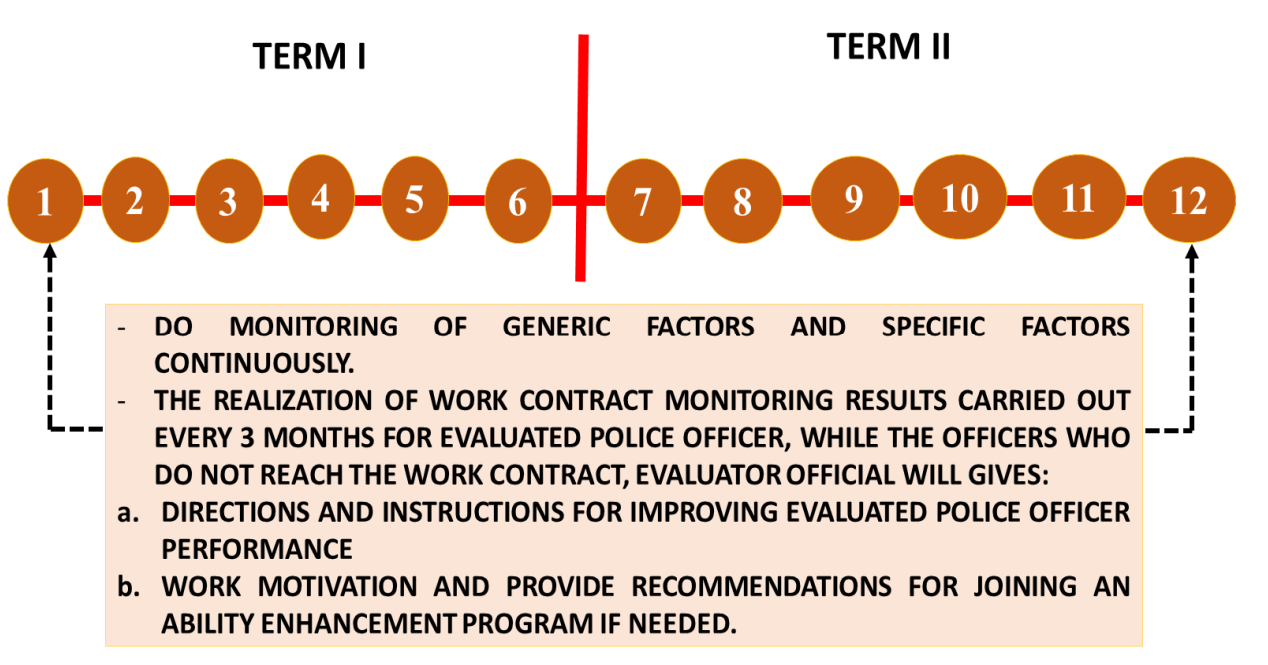

Source: SSDM Polri, 2019

Figure 4. Activities in Performance Appraisal for Monitoring Performance Achievement Targets 
Furthermore, in the context of (1) Periodic monitoring of specific factors (FS) and generic factors (FG) as well as (2) the results of coordination of work contracts every 3 not for AYD that do not reach the target of the work contract, then help provide: (1) directions and instructions for restoring AYD performance; and (2) provide work motivation and if needed provide assistance for capacity building programs. In supporting the improvement of the online-based performance management system of the National Police, even the Surabaya Resort Police Leadership made the following innovations.

First, Prize. In early 2019 members of Surabaya Resort Police who excelled, specifically 3 Trafic Units members received free Umrah prizes. The awarding is a form of appreciation for Satlantas units that have good performance with good predicate. The implementation of this reward is in line with the opinion of [16], [29], [30] who explain one of the basic objectives of reward is to motivate members of the organization. The purpose of this consideration is that an unbalanced system or rewards designed by the company to spur the work of its employees can improve their performance at work.

Second, Punishment. When a member decides to impose discipline as an oral reprimand and must report to the leader, with the aim of being able to improve the attitude of the member. If the approval occurs 3 times, discipline will be entered into the session and the decision of the hearing is the right of leadership approval.

This implementation penalty is in line with the opinion of [30], [31] explains that punishment is a punishment for being submitted for violators, changing the applicable regulations and giving lessons to violators.

Secondly, in order to improve the management system, the online-based National Police, which has been carried out by Surabaya Police, is expected to be able to improve the performance of the Indonesian National Police in Surabaya Police which prioritizes educating and providing learning to personnel, not just providing deterrence.

\section{Conclusion}

the Indonesian National Police Performance Assessment initially used the list of values. But its value is incompetent with current developments. For this reason, the revision of Law Number 16 of 2011 concerning Performance Appraisal of the Civil Servants of the Republic of Indonesia with the Performance Management System becomes the Regulation of the Indonesian National Police Chief Number 2 of 2018 concerning Performance Evaluation of Indonesian Members. National Police. This research uses qualitative. The results of the study of commitment to results only pursue formality and cancel participation. Lack of knowledge and awareness of people to Perkap No. 16 of 2011, led to the results of the assessment showing that the giving of gifts and innovative punishment such as giving free Umrah (for Muslims) and providing punishment that provides learning - namely verbal reprimands from superiors and compulsory reporting, becomes one of the keys to assist in increasing assistance 
for other Indonesian National Police Headquarters personnel is to stimulate work morale and increase competence in the field of each unit.

Acknowledgement The authors would like to thank the editors and the anonymous reviewer for the helpful and constructive feedbacks instrumental in improving this article. The first author gratefully thanks for Indonesian National Police Headquarters, while the second author thankfully thanks to the Hibah PITMA B 2019, Universitas Indonesia for funding of this study.

\section{References}

[1] Sulistiyanto and R. Fitriati, World Class Navy: Kepemimpinan Kolaboratif di Sekolah Staf dan Komando Angkatan Laut. Jakarta: m\&! Gramedia, 2020.

[2] W.-L. Chang, Pao-Long, Chen, "The Effect of Human Resource Management Practices on Firm Performance: Empirical Evidence from High-Tech Firms in Taiwan," Int. J. Manag., 2002.

[3] A. Aktar and F. Pangil, "The relationship between employee engagement, HRM practices and perceived organizational support: evidence from banking employees," Aktar, A. Pangil F.(2017), "The Relatsh. between Empl. Engag. HRM Pract. Perceived Organ. Support Evid. from Bank. Employees” Int. J. Hum. Resour. Stud., vol. 7, no. 3, 2017.

[4] G. T. Marx, "Police and Democracy (From Policing, Security and Democracy: Theory and Practice, P 35-45, 2001, Menachem Amir, Stanley Einstein, eds.,--See NCJ192667)," 2001.

[5] M. Amir and S. Einstein, Policing, security, and democracy: Theory and practice. Office of International Criminal Justice Huntsville, TX, 2001.

[6] W. S. Jacobson and J. E. Sowa, "Strategic Human Capital Management in Municipal Government," Public Pers. Manage., vol. 44, no. 3, pp. 317-339, 2015, doi: $10.1177 / 0091026015591283$.

[7] W. Jamal and M. Saif, "Impact of Human Capital Management on Organizational Performance,” Eur. J. Econ. Financ. Adm. Sci., vol. 34, pp. 55-69, Jul. 2011.

[8] D. Kosiorek and K. Szczepanska, "Relationships between organisational culture and human resource management," Jagiellonian J. Manag., vol. 2, no. 3, pp. 205-215, 2016, doi: 10.4467/2450114XJJM.16.016.5848.

[9] E. Ennimay and H. Efendy, "Implementation of Human Capital Management in HR Section of the Hang Tuah School of Health Science (STIKES) Pekanbaru," Int. J. Hum. Resour. Stud., vol. 8, no. 1, pp. 17-37, 2018, doi: 10.5296/ijhrs.v8i1.11984.

[10] A. Kucharčíková, M. Miciak, and M. Hitka, "Evaluating the Effectiveness of Investment in Human Capital in E-Business Enterprise in the Context of Sustainability," Sustainability, vol. 10, no. 9, p. 3211, Sep. 2018, doi: 10.3390/su10093211. 
[11] J. Shane, "Performance management in police agencies: A conceptual framework," Policing-an Int. J. Police Strateg. Manag. - Polic., vol. 33, no. 1, pp. 6-29, Mar. 2010, doi: 10.1108/13639511011020575.

[12] M. Moore and A. Braga, "Measuring and improving police performance: The lessons of Compstat and its progeny," Polic. An Int. J. Police Strateg. Manag., vol. 26, no. 3, pp. 439-453, Sep. 2003, doi: 10.1108/13639510310489485.

[13] B. Metcalfe and G. Dick, "Exploring organisation commitment in the police Implications for human resource strategy," Polic. An Int. J. Police Strateg. Manag., vol. 24, no. 3, pp. 399-419, 2001.

[14] J. Ding, Q. Zheng, X. Wang, H. Zhu, and J. Zhang, "Assessment of Innovative Performance Management in Chinese Police System: A Case Study of Zhejiang Province," Public Pers. Manage., vol. 45, Feb. 2016, doi: 10.1177/0091026016630368.

[15] T. Luen and S. Hawamdeh, "Knowledge management in the public sector: Principles and practices in police work," J. Inf. Sci., vol. 27, no. 5, pp. 311-318, Oct. 2001, doi: $10.1177 / 016555150102700502$.

[16] N. Mustapha and Z. C. Zakaria, "The effect of promotion opportunity in influencing job satisfaction among academics in higher public institutions in Malaysia," Int. J. Acad. Res. Bus. Soc. Sci., vol. 3, no. 3, p. 20, 2013.

[17] Kepolisian Negara Republik Indonesia, "Peraturan Kapolri Nomor 2 Tahun 2018 tentang Penilaian Kinerja Anggota Kepolisian Negara Republik Indonesia dengan Sistem Manajemen Kinerja," 2018.

[18] Kepolisian Negara Republik Indonesia, "Peraturan Kapolri Nomor 16 Tahun 2011 tentang Penilaian Kinerja Bagi Pegawai Negeri,” 2011.

[19] S. Nadarajah, V. Kadiresan, R. Kumar, N. N. A. Kamil, and Y. M. Yusoff, "The relationship of HR practices and job performance of academicians towards career development in Malaysian private higher institutions," Procedia-Social Behav. Sci., vol. 57, pp. 102-118, 2012.

[20] S. Pule, J. Mwesigye, E. Kanyangabo, and R. Mbago, "Human resource policy and job satisfaction of employees in Knowledge-based enterprises: A comparative study of the Indigenous and expatriate teaching staffs of Kampala International University, Uganda," Glob. J. Hum. Resour. Manag., vol. 2, no. 3, pp. 13-27, 2014.

[21] J. W. Creswell, Educational research: planning, conducting, and evaluating quantitative and qualitative research. 2015.

[22] J. W. Creswell and V. L. Plano Clark, Designing and conducting mixed methods research. 2018.

[23] C. Teddie and A. Tashakkori, Foundations of mixed methods research: integrating quantitative and qualitative approaches in the social and behavioral sciences. Thousand Oaks: Sage Publications, 2009.

[24] C. Marshall and G. B. Rossman, "Designing qualitative research [Kindle version]." Sage, 2011. 
[25] K. G. Esterberg, "Qualitative methods in social research," 2002.

[26] R. L. Mathis, J. H. Jackson, and S. Valentine, Human resource management. 2014.

[27] G. Dessler, Fundamentals of human resource management. Pearson, 2013.

[28] S. D. A. Ambarwati, "Managing productive performance appraisal: Sebuah upaya menjawab kebutuhan penilaian kinerja karyawan yang bebas KKN," J. Siasat Bisnis, vol. 1, no. 7, 2002.

[29] E. K. Johnson, "The practice of human resource management in New Zealand: strategic and best practice?," Asia Pacific J. Hum. Resour., vol. 38, no. 2, pp. 69-83, 2000.

[30] S. Febrianti, "Pengaruh Reward dan Punishment Terhadap Motivasi Kerja Serta Dampaknya Terhadap Kinerja (studi pada karyawan PT. Panin Bank Tbk. Area Mikro Jombang)," J. Adm. Bisnis, vol. 12, no. 1, 2014.

[31] A. A. A. P. Mangkunegara, Manajemen sumber daya manusia perusahaan. Remaja Rosdakarya, 2000. 